\title{
KAJIAN AWAL TENTANG MONEY LAUNDERING SERTA IM PLIKASINYA DALAM PASAR KEUANGAN INTERNASIONAL
}

\author{
Hariyadi Ramelan, dan Delfianto Ras*)
}

Perkembangan teknologi perbankan internasional dalam dekadeterakhir ini telah memberikan jalan bagi tumbuhnyajaringan-jaringan perbankan yang semulalokal/regional menjadi suatu lembaga keuangan yang global. Kecenderungan tersebut ternyatajuga memberikan kesempatan bagi para pelaku money laundering untuk turut memanfaatkan kecanggihan jaringan layanan perbankan. U ang hasil transaksi ilegal (obat bius/ narkotika, senjata gelap, suap/korupsi/manipulasi serta fraud perbankan) telah menjadi "legal" dalam duniabisnis di pasar keuangan internasional. D alam posisi ini, perbankan internasional khususnyalnternational O ffshoreBanking Centres (IOBC) dengan segala aspek perlindungan data sertakeleluasaan pajaknyatelah menjadi lembagaintermediasi yang sangat diminati oleh para money launderer. $N$ amun pada sisi yang lain, juga merupakan lembaga yang sangat rentan terhadap proses placement, layering ataupun integration.

Tulisan ini bertujuan untukmemberikan gambaran awal tentang kegiatan money laundering; batasan, teknik-teknik, sumber-sumber regulasi, serta implikasi yang timbul sehubungan dengan peranan bank sebagai lembagaintermediasi. Kajian ini diharapkan akan mampu memberikan gambaran sertaperbaikan-perbaikan yang memadai dan perlu dilakukan oleh masyarakat keuangan internasional dalam upaya pencegahan maupun penindakan terhadap kegiatan money laundering, yang dari tahun ketahun semakin canggih, terorganisasi rapi dan profesional. Ketidakberhasilan dalam menggalang kerjasama internasional dalam memerangi money laundering akan menimbulkan risiko perubahan variabel permintaan uang yang takterduga, risiko pada kesehatan perbankan, efek kontaminasi pada transaksi keuangan yang legal, volatilitas yang sangat besar pada modal internasional dari transfer asset antar negarayang tidakterantisipasi.

$\begin{array}{ll}\text { Haryadi Ramelan } & \text { Dealer pada Dealing Room, Urusan Devisa, Bank Indonesia } \\ \text { Delfianto Ras } & \text { : Dealer Yunior pada Dealing Room, Urusan Devisa, Bank Indonesia }\end{array}$ 


\section{Pendahuluan}

$\mathrm{T}$

hewar against money launderer is not over . Kalimat tersebut nampaknya bukan sekedar slogan kosong bagi Pemerintah A merika Serikat dal am memberantas kegiatan money laundering. Hal tersebut paling tidak terbukti pada hasil "O peration Cassablanca" yang berlangsung akhir bulan Maret 1999. Dua bank besar Mexico, yakni Bancomer dan Banco Serfin dinyatakan bersalah oleh Pengadilan Federal (Fed Court) Los Angeles, dalam kasus money laundering. Dua bank besar tersebut diharuskan membayar denda masingmasing USD 9,9 juta dan USD 4,7 juta. Kedua bank juga terbukti bersalah dan mengaku bertanggung jawab penuh bahwa karyawan-karyawan banknya telah melakukan money laundering atas hasil-hasil ilegal narkotik. Pada saat yang bersamaan di London, Dinas Pajak Dalam Negeri Inggris melakukan razia terhadap 2 kantor akuntan besar dan juga rumah pengacara serta akuntan yang terbukti berupaya menghindari objek pajak yang diperoleh dari money laundering. Contoh-contoh tersebut hanya menggambarkan situasi mikro dari satu konsekuensi bercampurnya "uang halal" yang secara resmi masuk dalam hitungan otoritas moneter dengan uang haram yang merupakan hasil kegiatan melawan hukum dalam bisnis keuangan internasional.

Padasituasi global, kegiatan money laundering dalam konsep akuntansi internasional ternyata mampu menjelaskan adanya defisit neraca transaksi berjalan dunia. Secara teoritis dan teknis, penjumlahan total nilai import dan pembayaran bunga seharusnya sama dengan total nilai ekspor dan penerimaan bunga. Secara lebih rinci, bila sebuah komoditas diimpor dan dibayar, namun tidak ada catatan bahwa seseorang telah menerima pembayaran tersebut. Lantas kemanakah uangnya? Beberapa sebab dapat dikemukakan seperti statistical error atau (bukan mustahil) adanya secret money. Hal kedua tersebut diakui sebagai masalah yang pelik namun realitasnya memang terdapat permintaan pasar yang cukup kuat untuk secret money, tidak hanya dari para kriminal namun juga dari perusahaan-perusahaan dan bahkan pemerintahan. Dalam kasus black hole di atas, ${ }^{1)}$ uang yang dibayarkan untuk barang atau jasa-jasa tersebut tidak pernah tercatat oleh perusahaan/ individu yang umumnya dengan berbagai alasan antara lain untuk menghindari pajak ataupun karena transaksi tersebut ilegal (manipulasi oleh perusahaan swasta, suap kepada pejabat pemerintahan, dII).

Sejalan dengan praktek money laundering tersebut, saat ini perkembangan pasar keuangan internasional telah memungkinkan terbukanya peluang untuk menampung rekening secret money. Hal ini antara lain ditandai dengan semakin maraknyalnternational O ffshoreBanking Centers (IOBC) di berbagai belahan dunia seperti Gambar 1.

1. Samuel, J.M et al. 1996. Management of Company Finance, $6^{\text {th }}$ Ed. pp.22-23. Chapman \& Hall, London. 
Berkaitan dengan permasalahan tersebut, International M onetary Fund (IMF) ${ }^{2)}$ berpendapat bahwa money laundering merupakan salah satu ancaman paling serius bagi masyarakat keuangan internasional khususnya dan sistem keuangan global padaumumnya. Sebagai gambaran turn over kegiatan money laundering saat ini telah melampaui batas imaginasi, yakni 2-5\% dari GDP dunia, yang besarnya mencapai 300 - 400 milyar USD. Angka ini secara ekstrim dapat diartikan bahwa bisnismoney laundering merupakan bisnis terbesar ketiga di dunia setelah forex market dan bisnis minyak dunia.

Tujuan dari penulisan makalah ini antara lain memberikan gambaran yang menyeluruh berkaitan dengan kegiatan money laun dering, batasan, trend dan teknik umum yang digunakan, serta implikasinya bagi pelaku-pelaku transaksi-transaksi perbankan internasional seperti bankir, regulator atau lembaga lain yang berwenang (bank sentral) serta pelaku-pelaku pasar finansial lainnya.

Dengan memiliki pemahaman yang cukup memadai, maka diharapkan dapat diupayakan langkah-langkah efektif untuk mencegah terjadinya money laundering maupun langkah-langkah represif seandainya money laundering terjadi dengan tetap mengacu pada Undang-undang ataupun regulasi yang berlaku secara internasional.

Secara rinci, bagian kedua tulisan ini akan memaparkan batasan, proses kegiatan dan pelanggaran money laundering. Bagian Ketiga, mengupas beberapa implikasi yang sifatnya represif dan antisipatif terhadap kegiatan money laundering dan Bagian Keempat berisi Kesimpulan akhir.

\section{Batasan, Teknik dan Regulasi dalam Kegiatan Money Laundering}

\section{A. Batasan dan Proses Kegiatan Money Laundering}

Tak ada batasan money laundering secara umum, namun demikian money laundering secara khusus dapat diartikan pencucian uang (laundering money from illicit proceeds), yakni sebagai suatu proses dimana para kriminal berupaya untuk menyembunyikan sumber dan kepemilikan hasil-hasil aktivitaskriminal yang melawan hukum. Dalamtextbook, ada empat faktor yang umum terdapat dalam kegiatan mon ey laundering. Pertama, pemilik uang dan sumber sesungguhnya uang tersebut harus disembunyikan. Kedua, bentuk pengambilan uangnya harus diubah. Ketiga, jejak proses pencucian uang harus disamarkan dalam upaya menghilangkan jejak jika seseorang menel usuri proses uang dari awal hingga akhir. Keempat, pengawasan melekat terhadap uang (dirty money) harus dipertahankan. 
Secara kronologis, kegiatan money laundering biasanya terdiri atas 3 proses yang berkelanjutan yakni:

\section{Placement (Penempatan D ana)}

Penempatan dana merupakan proses awal dalammoney laundering yang ditandai dengan penyerahan secara fisik uang yang dihasilkan dari aktivitas melawan hukum seperti perdagangan narkotika, obat-obatan terlarang, senjata gelap, penipuan/ penggelapan (fraud) serta hasil-hasil korupsi. Langkah ini disebut juga sebagai immersion yang merupakan gabungan dari consolidation dan placement (Robinson, J, 1998) ${ }^{3)}$.

\section{Layering (Pemilahan D ana)}

Layering atau heavy soaping merupakan langkah kedua dalam money laundering yang ditandai dengan pemilahan hasil-hasil ilegal tersebut dari sumber-sumber asalnya melalui pembelian/ transaksi-transaksi finansial seperti bearer bonds, for ex market, stocks. Langkah lain yang sering dilakukan adalah menciptakan sebanyak mungkin account dari perusahaan fiktif/semu dengan memanfaatkan aspek kerahasian bank dan keistimewaan hubungan antara nasabah bank dan pengacara. Hal ini dilakukan dalam upaya untuk menghilangkan jejak atau upaya audit sehingga seolah-olah merupakan transaksi finansial yang legal.

\section{Spin Dry (Repatriation and Integration)}

Spin dry merupakan gabungan dari langkah repatriasi dan integrasi. Proses yang terjadi adalah apabila hasil-hasil ilegal dari money laundering masuk kembali kedalam sistem keuangan dan muncul sebagai dana-dana bisnis yang wajar/ normal. Secara ringkas, proses pencucian yang dapat dilihat pada Gambar 2. Proses Pencucian Uang.

\section{B. Teknik-Teknik Money Laundering}

Berdasarkan survey yang dilakukan oleh TheFATF ${ }^{4)}$ (TheF inancial A ction Task Force) sepanjang tahun 1996-1997, teknik-teknik yang dilakukan dalam pencucian uang dapat dikategorikan dalam 2 cara umum yakni:

1. Cara tradisional.

Cara tradisional dalam money laundering adalah dengan cara menyelundupkan secara fisik uang tunai hasil transaksi ilegal keluar negeri (perbatasan nasional suatu negara). Caralain yang juga relatif konvensional adalah menggunakan pedagang valuta asing, lawyers maupun akuntan pribadi. Penggerebekan yang terjadi di London pada contoh 
122 Buletin E konomi Moneter dan Perbankan, Maret 1999 
kasus di atas jelas menunjukkan kecurangan seorang pengacara/ akuntan dalam menyembunyikan hasil-hasil kejahatan seperti money laundering.

\section{Cara-cara Modern.}

Berkembangnya teknologi baru dibidang perbankan antara lain elektronic money (emoney) telah memberikan ancaman baru dalam teknik money laundering yang lebih canggih. Tiga cara yang mungkin dilakukan adalah melalui : Stored val uecards, internet/ network based systems dan hybrid systems. Namun demikian, aplikasi ke tiga cara ini dalam sistem pembayaran masih relatif belum termanfaatkan. Hal yang sulit untuk dilacak justru hasil-hasil ilegal yang ditransfer melalui International Electronic Fund Transfer. Berdasarkan pengalaman di Inggris, ciri-ciri yang sering dilakukan oleh money launderer antara lain menggunakan institusi yang terkait (perbankan) serta Pedagang ValutaAsing (PVA), lawyer, sertaaccountant.

\subsection{Bank sebagai money launderer}

Salah satu contoh yang sangat berharga berkaitan dengan kasus money laundering adalah skandal yang dilakukan oleh TheBank of Credit and Commerce International (BCCl) pada tahun 1991. Bank yang didirikan di Luxembourg tahun 1972 oleh pengusaha Pakistan (Agha Hasan A bedi), dalam perjalanannya asset bank tumbuh dengan cepat hingga mencapai USD 20 milyar dan mempunyai cabang di 70 negara. Namun sayangnya bank tersebut mengirimkan dananya ke rekening rahasia di Cayman Islands, dimana tempat tersebut banyak uang hasil curian. Diperkirakan hampir setengah assets bank telah hilang (disappeared). Penggelapan uang tersebut tidak hanya menjadi kegiatan bayangan $\mathrm{BCCl}$, namun $\mathrm{BCCl}$ diperkirakan juga membantu diktator seperti Sadam Hussein (Irak), Manuel N oriega (Panama) dan Ferdinand Marcos (Philipina) dalam mencuri uang dari negaranya, serta bertindak sebagai bankir dari kelompok Abu Nidal. Tidaklah mengejutkan bila $\mathrm{BCCl}$ diplesetkan artinya menjadi "Bank of Crook and Criminals, Inc".

Bagaimana $\mathrm{BCCl}$ menjalankan aktivitas penggelapan dalam waktu yang cukup lama? Jawabannya adalah sulitnya mengatur bank yang beroperasi di banyak negara. Meskipun kantor pusat BCCI di London, namun lemahnya peraturan bank oleh Institut M onetaire L uxembourgeois (IML) di Luxembourg, mengakibatkan BCCI beroperasi bebas dari peraturan pemerintah selama 15 tahun. Pada tahun 1987, IML mencapai persetujuan dengan tujuh negara dimana $\mathrm{BCCl}$ beroperasi, tetapi masih belum dapat menelusuri aktivitas bank tersebut. Pada musim semi tahun 1990 IML dapat menemukan beberapa bukti penggelapan dan pada Juli 1991 perusahaan akuntan PriceWaterhousemenemukan dokumen serta menyerahkan pada Bank of England, selanjutnya BCCI dinyatakan ditutup. Kerugian deposan 
dan pemegang saham dari colapse-nya $\mathrm{BCCl}$ sudah tak terhingga dan pengawas bank dalam hal ini Bank of Engl and sulit disalahkan atas kelambanan menuntaskan skandal tersebut. Setahun setelah $\mathrm{BCCl}$ colapse, the Basle Committee baru mengumumkan dan menyetujui standarisasi dari peraturan bank internasional.

\subsection{Payable through account}

Salah satu cara yang juga tergolong cukup modern dan sering digunakan oleh money launderers adalah payable through account (lihat Gambar 3). Pada gambar tersebut diilustrasikan adanya pembelian U S bonds yang pembayarannya dilakukan melalui account oleh client bank yang kemudian diperjual belikan padalevel nasabah client bank tersebut (third bank) dan diteruskan pada level nasabah third bank. Melalui transaksi beberapa jenjang tersebut pada level terbawah yaitu pada level nasabah third bank tersebut para money launderers banyak melakukan aktivitasnya untuk memasukkan dananya ke dalam sistem jasa keuangan bank.

\section{Regulasi Kegiatan Money Laundering}

Sebagaimanadiketahui, bank ataupun lembaga finansial lainnya merupakan lembagalembaga yang sangat rentan bagi kemungkinan penyusupan hasil-hasil transaksi ilegal (secret money). Rentannya lembaga-lembaga tersebut dari kegiatan money laundering dimungkinkan baik dalam proses placement, layering maupun integration.

Berkaitan dengan upaya untuk mencegah dan memerangi kegiatan money laundering tersebut, perlu adanya aturan hukum yang mengikat secara internasional dan berkekuatan hukum yang tetap. Rezim yang dapat dijadikan contoh untuk pencegahan kegiatan money laundering adalah Inggris. Mengapa demikian, karena London sebagai salah satu pusat pasar keuangan terbesar dunia, merupakan target yang menarik bagi para pencuci uang. Pasar finansial London yang terkenal dengan kemajuan dan transparannya sangat memberi peluang untuk memuluskan tahapan-tahapan kegiatan money laundering, apakah itu placement, layering dan integrasi. Kondisi ini lebih membuka peluang setelah diperkenalkan Euro sebagai mata uang tunggal Eropa yang secara tidak langsung telah menurunkan kontrol dan hambatan-hambatan dalam rangka pasar tunggal Eropa, khususnya untuk mobilitas barang-barang, jasa, orang dan modal secara leluasa di seluruh Eropa.

Dalam rangka merespon hal-hal tersebut di atas, beberapa ketentuan perundangan telah disahkan oleh oleh Parlemen Inggris, yakni antara lain:

1. Ketentuan Primer (Tier 1)

1) Drug Trafficking Offences Act 1986 (DTOA)

2) Criminal JusticeScotland Act 1987 (CJSA) 
Kajian A wal Tentang M oney L aundering serta Implikasinya dalam Pasar Keuangan Internasional $\mathbf{1 2 5}$ 
3) Criminal JusticeAct 1988(CJA 88)

4) Prevention of Terrorism (Temporary Provisions) Act 1989(POTA)

5) Criminal Justice(Int. Cooperation) Act 1990 (CJCA)

6) Criminal Justice (Confiscation) (N orthern Ireland) Order CJO 1990

7) Northern Ireland Act 1991, (NIEPA)

8) Criminal JusticeAct 1993(CJA 93)

\section{Ketentuan Sekunder (Tier 2)}

Ketentuan sekunder yang merupakan bentuk dari M oney Laundering Regulation 1993 secara khusus ditujukan pada lembaga keuangan. Peraturan tersebut mensyaratkan bagi semua lembaga keuangan, dan sejenisnya untuk membuat sistem untuk menghalangi terjadinya money laundering. Prosedur pencegahan terhadap terjadinya money laundering yang umumnya digunakan pada lembaga- lembaga keuangan adalah sebagai berikut:

a) Sistem Kontrol.

Sistem ini berupa peraturan yang meliputi prosedur internal control dan komunikasi tepat pada lembaga-lembaga keuangan yang bertujuan mencegah dan menghalangi terjadinya money laundering.

b) Identifikasi dan Verifikasi.

Setiap calon nasabah harus diidentifikasi dan diverifikasi bahwa yang bersangkutan memang memenuhi syarat sebagai applicant for business.

c) Uji/Pemeriksaan atas Transaksi.

Ketentuan ini menjamin pegawai dari waktu kewaktu diberikan kesempatan mengikuti pelatihan dalam upaya mengenali dan menguasai transaksi yang dilakukannya sendiri atau atas nama orang lain , yang sangat berpotensi dimanfaatkan pihak lain untuk money laundering.

d) Pencatatan.

Dalam kaitan ini, pencatatan dapat dibagi dua yaitu, pencatatan yang berhubungan dengan pembukaan rekening nasabah baru (client) atau identitas counterparty dan pencatatan yang berhubungan dengan transaksi yang dilakukan oleh client atau counter party.

e) Pelaporan.

Prosedur pelaporan antara lain mencakup laporan identifikasi orang dalam suatu organisasi , kepada siapa informasi tersebut harus dibuat; apa jenis informasinya; masalahmasalah yang muncul dan pegawai yang menanggulanginya; pendapat orang yang menanggulangi masalah tersebut dalam upaya meningkatkan pengetahuan terutama mengenai dasar kecurigaan terhadap orang yang melakukan money laundering.

f) Pendidikan dan Pelatihan.

Prosedur ini sangat dibutuhkan bagi seluruh personil perbankan dan lembaga terkait 
dalam upaya peningkatan kual itas pemahaman terhadap pekerjaan yang dijalani serta kontribusinya terhadap pengawasan internal.

\section{g) Tindakan hukum.}

Prosedur ini merupakan langkah terakhir yang harus dilakukan dan biasanya berupa investigasi oleh $\mathrm{N}$ ational Criminal Inteligent Service(NCIS).

\section{Ketentuan Tambahan (Tier 3)}

Ketentuan tambahan ini lebih merupakan petunjuk teknis yang diterbitkan oleh The Joint M oney Laundering Steering Group (JMLSG) yang ditujukan bagi bank-bank dan lembaga keuangan lainnya, asuransi dan lembaga investasi lainnya. Buku ketentuan ini biasanya disebut sebagai the read book untuk perbankan, yellow book untuk bisnis investasi swasta, dan green book untuk bisnis asuransi.

\section{Pelanggaran Hukum dalam M oney Laundering}

Berdasarkan perundangan di Inggris (Criminal Justice Act 1993/ CJA) tersebut di atas, terdapat 5 pelanggaran utama yang dapat dikategorikan sebagai tindakan money laundering, yaitu:

a) Membantu seseorang untuk menyimpan hasil-hasil kejahatan. Tindakan ini digolongkan sebagai pelanggaran bagi seseorang yang memberikan bantuan kepada money launderer untuk memperoleh, menyembunyikan, menguasai, atau menginvestasikan danajika dana yang bersangkutan diketahui atau dicurigai merupakan hasil penerimaan kriminal.

b) Mengakuisisi , memiliki , dan menggunakan hasil dari kegiatan kriminal. Seseorang dianggap bersalah melakukan pelanggaran jika dia mengetahui sebagian atau kesel uruhan kekayaan orang lain baik secara langsung atau tidak langsung berasal dari hasil kejahatan, dan secara langsung atau tidak langsung dia menguasai atau menggunakan atau memiliki kekayaan tersebut.

c) Menyembunyikan atau mentransfer penerimaan untuk menghindari tindakan pencegahan atau perintah penyitaan. Dibawah aturan CJA seseorang dianggap melakukan pelanggaran apabila menyembunyikan, menyamarkan, mengubah, melakukan transfer atau menyembunyikan kekayaan dari pengadilan baik secara langsung maupun tidak langsung, seluruh atau sebagian penerimaan yang berasal dari kegiatan kriminal.

d) Menggagalkan usaha penyingkapan atau kecurigaan dari praktek money laundering. CJA mensyaratkan siapapun sehubungan dengan transaksi yang dilakukan, profesi, bisnis, atau pegawai yang mengetahui atau mencurigai orang lain melakukan money laundering 
harus melaporkan informasi tersebut pada polisi sesegeramungkin. CJA hanyamentolerir kesalahan atas kecurigaan yang dilaporkan dengan alasan yang dapat diterima.

e) Tipping off (Peringatan). Suatu pemaksaan terhadap keterbukaan konsumen atau pihak ketiga untuk menyampaikan informasi pada pihak yang berwenang bahwatelah terjadi praktek money laundering atau adanya rencana money laundering. Hal ini berarti bahwa seseorang dianggap melanggar hukum apabila tidak melaporkan kepada pihak berwenang apabila mengetahui adanya praktek money laundering.

\section{Beberapa Upaya Represif dan Antisipatif terhadap Kegiatan M oney Laundering}

Sebagaimana diuraikan di atas, kegiatan money laundering memiliki dampak instabilitas padasistem finansial dunia. Faktor instabilitas tersebuttidak hanya bersumber dari turn over yang sangat besar (300-400 milyar USD per tahun), namun juga berasal dari perkembangan teknologi seperti EFT (cyber payment) yang memungkinkan pembayaran transfer berlangsung dengan mobilitas yang tinggi dengan mengoptimalkan jaringan perbankan internasional sebagai lembaga intermediasi.

Kondisi ini memberikan suatu implikasi yang sangat luas dan kompleks dalam upaya menciptakan kestabilan masyarakat global di pasar finansial. Implikasi tersebut menuntut adanya suatu langkah kerjasama preventif dan represif yang berskala internasional terhadap kegiatan money laundering. Satu upaya upaya penting yang telah dilakukan oleh masyarakat internasional adalah dibentuknya FATF yang salah satu rekomendasinya menyatakan bahwa "countries should monitor the physical cross border transportation of cash and bearer instruments without impeding in any way the freedom at capital movement". Rekomendasi ini merupakan kunci utama dalam pemahaman konsep "know your customer" approach.

Sejalan dengan hal tersebut, BIS melalui Basle Committee pada bulan September 1997 juga menetapkan prinsip utama dalam supervisi perbankan yang efektif yang berbunyi “ Banking supervisor must determine that banks have adequate policies, practices and procedures in place, including strict "know your customer" rules, that promotehigh ethical and professional standards in thefinancial sector and prevent the bank being used, intentionally or unintentionally, by criminal elements".

Dalam kaitan di atas, FATF memberikan 40 rekomendasi langkah-langkah utama dalam memerangi kegiatan mon ey laundering, yang secara pokok dapat dijabarkan sebagai berikut:

a) Introduksi sistem SAR (suspicious activity reporting system) yang baru.

b) Modifikasi sistem pelaporan transaksi matauang ( $C T R=$ Currency Transaction Reporting System). 
c) Perluasan daftar tindakan pelanggaran money laundering dalam memberantasterorisme, pelanggaran migrasi dan kesehatan.

d) Peningkatan kerjasama antar negara dan perwakilan industri keuangan global dalam upaya melawan kegiatan mon ey laun dering melalui penetapan kelompok kerja.

e) Implementasi proyek Gateway yang menyediakan data-data inteligen keuangan secara on lineantar negara dan pemerintah-pemerintah daerah.

f) Penetapan aturan baru dalam pencatatan transfer-transfer dana (system at determine internal control, policies and prosedures).

g) Memperluas upaya pelaksanaan hukum dan pengaturan hukum dalam memerangi kegiatan money laundering.

h) Staff Training : dalam rangka mengenali dengan baik dan menangani transaksi-transaksi yang mencurigakan, staf pelaksana harus menerima pelatihan khusus money laundering. 5 kelompok yang diharuskan mengikutinya adal ah:

1. Pegawai baru ( $\mathrm{N}$ ew employees).

Pelatihan terhadap pegawai baru sebaiknya mencakup latar belakang terjadinya money laundering; pelaporan kondisi yang terjadi; jaminan hukum yang dilaporkan; dan jaminan perorangan menurut ketentuan yang berlaku.

2. D ealers and sales staff.

Pelatihan terhadap dealer/ staf lainnya seharusnyajuga mencakup tanggung jawab secara hukum; pengenalan terhadap faktor-faktor yang mencurigakan; kebijaksanaan perusahaan terhadap adanya kasus-kasus pengecualian; sistem pelaporan; dealing dengan customer yang jarang dilakukan (antara lain transaksi kas dalam jumlah besar/ bearer securities).

3. A ccount 0 pening staff.

Pelatihan terhadap petugas front office harus meliputi prosedur-prosedur identifikasi dan verifikasi ( sebagai contoh, pengecekan akan kecocokan identitas investor), mengenali secara baik prosessettlement/payment/delivery instructions yang diluar batas kewajaran.

4. Supervisors/M anager.

Pelatihan terhadap manajer yang memberikan instruksi, lebih ditekankan pada detail mengenai ketentuan perundang-undangan yang berlaku meliputi identifikasi, pencatatan, pelaporan prosedur serta tindakan pinalti.

5. Reporting 0 fficers.

Pendalaman materi pelatihan terhadap kelompok staf ini meliputi seluruh aspek perundangan-undangan, peraturan dan prosedur internal, validasi, dan laporan transaksi yang mencurigakan. 


\section{IV.Penutup}

Dari pokok-pokok rekomendasi yang diberikan oleh FATF di atas, dapat ditarik beberapakesimpulan sebagai berikut:

1. Dengan semakin berkembangnya kegiatan/ transaksi-transaksi illegal internasional, maka upaya pemberantasan terhadap kegiatan money laundering merupakan real test case bagi masyarakat dan sistem keuangan internasional. Mengapa demikian? Karena anti money laundering measures membutuhkan kerjasama internasional yang harus kondusif baik bersifat multilateral maupun bilateral (antar dua negara). Sebagaimana kita ketahui, bahwa setiap negara memiliki prioritas yang berbeda-beda khususnya dalam menghadapi kegiatan/ praktek money laundering. Perbedaan visi dan persepsi ini tentunya akan berimplikasi pada kelompok-kelompok kerjayang dibentuk oleh FATF.

2. Berkaitan dengan butir (1), para anggota kelompok kerja FATF ataupun masyarakat keuangan internasional sudah selayaknya menerapkan aturan-aturan standar minimum dalam upaya memerangi kegiatan money laundering misal nya keseragaman penggunaan sistem SAR, CTR maupun Gateway Intelligence System. Hal ini berarti, bahwa apabila terdapat negara-negara yang tidak mematuhi kesepakatan bersama tersebut akan mendapatkan pinalti yang dapat berupa punitive taxes atas transaksi-transaksi yang terbukti berkaitan dengan money laundering di pasar finansial di negara yang bersangkutan, ataupun tidak diakuinya transaksi keuangan yang terjadi di negara tersebut secara internasional (default).

3. Konsekwensi lain, khususnya bagi lembaga pengawas perbankan ataupun lembaga keuangan lainnya, adalah bahwa kualitas supervisi terhadap transaksi finansial oleh bank khususnya harus senantiasa ditingkatkan. Peningkatan tersebut dapat diupayakan dalam bentuk investigasi khusus terhadap asal modal disetor, asal dana-dana pihak ketiga yang diterima, dan transaksi finansial yang dilakukan khususnya transaksitransaksi off bal ance sheet. Hal ini sangat penting mengingat dalam banyak kasusmoney laundering, lembaga perbankan seringkali dipergunakan sebagai intermediasi oleh pelaku tindakan kriminal yang tidak mustahil juga dibantu oleh adanya moral hazard oleh karyawan bank sendiri (contoh kasus BCCl, 1991).

4. Secara taktis, tindakan yang paling efektif dalam menangkal kegiatan mon ey laundering pada lembaga perbankan adalah mendeteksi sedini mungkin aktivitas kriminal tersebut pada titik paling crucial yakni pada saat hasil-hasil ilegal tersebut masuk ke dalam sistem perbankan/ keuangan (placement process). Dalam konteks ini maka pendekatan "know your customer rule" menjadi acuan yang sangat mendasar dalammenggali informasi calon nasabah bank. Jika langkah preventif ini diterapkan secara universal terhadap semualembagakeuangan/ jaringan perbankan internasional, maka kecil kemungkinan 
money launderer akan mampu menembusnya. Sebaliknya bila langkah tersebut tidak berhasil, maka money launderer akan selalu mencari titik terlemah dari sistem jaringan keuangan internasional, baik melalui International offshore Banking Centre (IOBS) yang memiliki insentif pembebasan pajak dan longgarnya peraturan ataupun memanfaatkan negara-negara/ lokasi yang relatif tidak/ belum terjangkau oleh hukum internasional.

\section{D aftar Pustaka}

1) A brahamson, Jeffrey.1996. M oney Laundering: Butterworths. Journal of International Banking and Financial Law, July - August.

2) Camdesus, M ichael.1998. M oney Laundering: The Importance of International Countermeasures, Paris (Feb 10).

3) Hayaes, Andrew .1996. Payable Through A ccounts and M oney Laundering. Legal A nalysis. Pp 29-31.

4) M orris, Allan.1995. M oney Laundering: The Regim in the U nited Kingdom, pp 350.

5) Parlour, Richard.1995. International Guideto M oney Laundering and Practice, Butterworths.

6) Reuters N ews.1999(March 31). Bancomer and Banca serfin Plead Guilty to M oney Laundering.

7) Richard, Barry, et al.1998. Guide to Financial Services Regulation, $3^{\text {rd }}$ Edition, $\mathrm{CCH}$ Inc. Illinois, USA.

8) Robinson, Jeffrey.1998. Laundrymen, Pocket Books, London.

9) The Banker, 1998 (Feb). M oney Laundering: The Sky's the Limit, pp 52-53.

10) . 1997. TheFinancial A ction Task Force on M oney Laundering, Annual Report. 